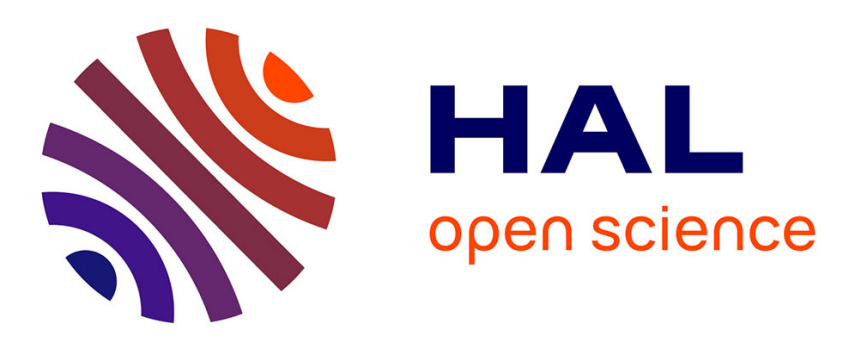

\title{
Diversity of ophiostomatoid fungi associated with the large pine weevil, Hylobius abietis, and infested Scots pine seedlings in Poland
}

Robert Jankowiak, Piotr Bilański

\section{- To cite this version:}

Robert Jankowiak, Piotr Bilański. Diversity of ophiostomatoid fungi associated with the large pine weevil, Hylobius abietis, and infested Scots pine seedlings in Poland. Annals of Forest Science, 2013, 70 (4), pp.391-402. 10.1007/s13595-013-0266-z . hal-01201480

\author{
HAL Id: hal-01201480 \\ https://hal.science/hal-01201480
}

Submitted on 17 Sep 2015

HAL is a multi-disciplinary open access archive for the deposit and dissemination of scientific research documents, whether they are published or not. The documents may come from teaching and research institutions in France or abroad, or from public or private research centers.
L'archive ouverte pluridisciplinaire HAL, est destinée au dépôt et à la diffusion de documents scientifiques de niveau recherche, publiés ou non, émanant des établissements d'enseignement et de recherche français ou étrangers, des laboratoires publics ou privés. 


\title{
Diversity of ophiostomatoid fungi associated with the large pine weevil, Hylobius abietis, and infested Scots pine seedlings in Poland
}

\author{
Robert Jankowiak • Piotr Bilański
}

Received: 12 July 2012 / Accepted: 23 January 2013 / Published online: 15 February 2013

(C) INRA and Springer-Verlag France 2013

\begin{abstract}
- Context Bark beetles are known to be associated with fungi, especially the ophiostomatoid fungi. However, very little is known about role of pine weevils, e.g., Hylobius abietis, as a vector of these fungi in Europe.

- Aims The aims of our study were to demonstrate the effectiveness of $H$. abietis as a vector of ophiostomatoid fungi in Poland and to identify these fungi in Scots pine seedlings damaged by weevil maturation feeding.

- Methods Insects and damaged Scots pine seedlings were collected from 21 reforestation sites in Poland. The fungi were identified based on morphology, DNA sequence comparisons for two gene regions (ITS, $\beta$-tubulin) and phylogenetic analyses.

- Results Sixteen of the ophiostomatoid species were isolated and identified. In all insect populations, Leptographium procerum was the most commonly isolated fungus ( $84 \%$ ). Ophiostoma quercus was also found at a relatively high frequency (16\%). Other ophiostomatoid fungi were found only rarely. Among these rarer fungi, four species, Leptographium lundbergii, Ophiostoma floccosum, Ophiostoma piliferum and Sporothrix inflata, were isolated above $3 \%$. L. procerum was isolated most frequently and
\end{abstract}

\section{Handling Editor: Francois Lieutier}

Contribution of the co-authors Robert Jankowiak: writing the paper, collecting of samples, identification of fungi and analysing the data. Piotr Bilański: collecting of samples and analysing the data.

\section{R. Jankowiak $(\bowtie)$}

Department of Forest Pathology,

University of Agriculture in Kraków, Al. 29 Listopada 46,

31-425 Kraków, Poland

e-mail: rljankow@cyf-kr.edu.pl

\section{P. Bilański}

Department of Forest Protection, Forest Entomology and Climatology, University of Agriculture in Kraków,

Al. 29 Listopada 46,

31-425 Kraków, Poland was found in $88 \%$ of the damaged seedlings. S. inflata was isolated from $26 \%$, while $O$. quercus occurred in $10 \%$ of the seedlings.

- Conclusion This study confirmed that $L$. procerum and $O$. quercus were common associates of $H$. abietis, while others species were found inconsistently and in low numbers, indicating causal associations. H. abietis also acted as an effective vector transmitting ophiostomatoid species, especially $L$. procerum and $S$. inflata, to Scots pine seedlings.

Keywords Hylobius abietis · Insect-fungus interactions . Ophiostomatoid fungi $\cdot$ Pinus sylvestris $\cdot$ Weevil

\section{Introduction}

The large pine weevil, Hylobius abietis (L.) (Coleoptera: Curculionidae), is a serious pest in managed stands of young Scots pine and Norway spruce in Poland (Skrzecz and Moore 1997). This weevil is found throughout Europe, across northern Asia, and into Japan, and it causes heavy economic losses, especially in Scandinavia and central Europe (Grégoire and Evans 2004). In Europe, damage caused by $H$. abietis is a major problem for conifer forests in which cutting is an aspect of the silvicultural management system and in those with even-aged, young monocultures (Örlander et al. 1997). In recent years (1991-2010), $H$. abietis damage has affected new clear-cutting areas of approximately 20,000 ha in Poland (Tarwacki 2011). The high risk of $H$. abietis damage seen in many reforested sites is likely due to the optimal breeding conditions for larvae that develop in the stumps and root systems of trees after clearfelling. The adult weevils that emerge from the stumps then feed on the stem-bark of young seedlings from the root collar up. The extensive weevil attack reduces plant growth and often leads to death when the stems of seedlings are completely ring-barked (Wallertz et al. 2005). 
Bark beetles live in a close association with ophiostomatoid fungi (Ascomycota: Ophiostomatales) (Wingfield et al. 1993). The majority of ophiostomatoid species include the sexual genera Ophiostoma and the asexual genera Pesotum, Sporothrix and Hyalorhinocladiella, and Grosmannia with Leptographium anamorphs (Zipfel et al. 2006). The association between bark beetles and fungi may provide benefits to both parties. Fungi associated with bark beetles play very important roles in the degradation of difficult-to-decompose plant structures and provide the nutrient sources for the insects' development. They may protect bark beetle larvae against detrimental fungi and balance moisture in bark beetle galleries, and due to their phytopathogenicity, they may kill or accelerate the decline of stressed host trees. In turn, beetles act as vectors carrying fungal propagules with them to the nutrient-rich inner bark (Six 2003; Six and Wingfield 2011). Although the existence of a mutualistic relationship between phloem-feeding weevils and fungi remains unproven, Pestaña and Santolomazza-Carbone (2010) recently demonstrated that Pissodes castaneus (De Geer) benefits from the presence of Leptographium serpens (Goid.) M.J. Wingf. in Pinus pinaster Aiton in Spain. This provides evidence that weevils with a similar life strategy as bark beetles (development under the bark of trees) can be consistently associated with various microbes. We certainly know that phloem-feeding weevils act as effective transmission vectors of root-rot fungi, such as Heterobasidion annosum Fr. (Bref.) (Kadlec et al. 1992) and Armillaria spp. (Livingstone and Wingfield 1982), the rust pathogen Peridermium pini (Willd.) Lév. (Pappinen and von Weissenberg 1994) and the ophiostomatoid fungi (Viiri 2004). Most weevils are contaminated with fungal spores both internally (within the digestive tract) and externally (Viiri 2004). According to Lévieux et al. (1994), adults of $H$. abietis disperse fungal spores on the surface of their bodies, especially around the anterior part of the dorsal and lateral sides of the pronotum. Spores are located in cuticular depressions associated with the pronotal setae. These authors also speculated that the spores are additionally protected by secretions of the pronotal grandular apparatus.

Ophiostomatoid fungi are known to be associated with many regeneration weevils (Coleoptera: Curculionidae) in North America (Eckhardt et al. 2007; Hanula et al. 2002; Jacobs and Wingfield 2001; Nevill and Alexander 1992; Wingfield 1983; Zanzot et al. 2010). In the southeastern USA, loblolly pine (Pinus teada L.) decline is caused by Leptographium procerum (W.B. Kendr.) M.J. Wingf., Leptographium terebrantis S.J. Barras \& T.J. Perry and $L$. serpens and their curculionid vectors, including Hylobius pales (Herbst) and Pachylobius picivorus Germar (Eckhardt et al. 2007). In a recent study in Georgian longleaf pine (Pinus palustris Miller) stands, the same vectors were found to be infested with L. procerum; L. terebrantis; Grosmannia huntii (Rob.-Jeffr.) Zipfel, Z.W. de Beer \& M.J. Wingf.; Ophiostoma ips (Rumbold) Nannf. and other Ophiostoma and Pesotum species (Zanzot et al. 2010). In the northeastern USA, the fungal symbionts ( $L$. procerum and $L$. terebrantis) of $H$. pales and Pissodes nemorensis Germar were found to be an important mortality factor in white pine (Pinus strobus L.) root decline (Nevill and Alexander 1992). The same species of Leptographium and other ophiostomatoid fungi, including $O$. ips and $G$. huntii, are vectored by $H$. pales, $P$. picivorus and Hylobius radicis Buchanan and have been implicated as factors in the decline of red pine (Pinus resinosa Aiton) (Klepzig et al. 1991). In addition, a recently described species, Leptographium bhutanense X.D. Zhou, K. Jacobs \& M.J. Wingf., has been found in association with Hylobitelus chenkupdorjii Osella on Pinus wallichiana A.B. Jacks in Bhutan (Zhou et al. 2008).

The ecology of regeneration weevils and their associated fungi has already been well characterised in North America; however, information about European root-feeding weevilassociated ophiostomatoid fungi is very limited (Lévieux et al. 1994; Piou 1993). In France, H. abietis has been found carrying L. procerum, Leptographium wingfieldii $\mathrm{M}$. Morelet, Ophiostoma canum (Münch) Syd. \& P. Syd. and Ophiostoma piliferum (Fr.) Syd. \& P. Syd. (Piou 1993). Of all the fungi reported by Piou (1993), L. procerum was the most commonly observed. This species had also been isolated from dead Scots pine seedlings that were damaged by large pine weevil feeding. H. abietis was also shown to be associated with Leptographium alethinum K. Jacobs, M.J. Wingf. \& Uzunovic in England (Jacobs et al. 2001). The objectives of this study were (1) to determine the distribution and frequency of the ophiostomatoid species associated with H. abietis in Poland and (2) to determine whether adults of $H$. abietis introduce ophiostomatoid fungi to young live Scots pine seedlings during maturation feeding.

\section{Materials and methods}

\subsection{Beetle and seedling sampling}

Newly emerged $H$. abietis adults were collected from trap logs placed in 21 reforested stands of Scots pine in Poland during 2009-2011 (Fig. 1). The sites did not differ in tree species distribution before clear felling and were established on formerly Scots pine-dominated sites with a small mix of Quercus robur L. and Betula pendula Roth. All reforested areas were surrounded by managed Scots pine forests in various age classes. To obtain weevils, the trap logs (approximately 40 per site), $1.0 \mathrm{~m}$ long and $0.2 \mathrm{~m}$ in diameter, were laid on the soil in each reforestation site. Between April and May, 1,050 weevils (50 adults per site) were 
caught with sterile forceps and then stored individually in sterile microtubes $(1.5 \mathrm{~mL})$ for later fungal isolations. The adults were collected during maturation feeding when they walked upon or bit into the bark surface of trap logs. To perform the isolation, each weevil was removed from the storage microtube with sterilised tweezers and squashed onto the surface of a selective medium for Ophiostoma spp. (CMEA: $20 \mathrm{~g}$ malt extract, $20 \mathrm{~g}$ agar, $0.2 \mathrm{~g}$ tetracycline and $0.2 \mathrm{~g}$ cycloheximide; all per litre of distilled water).

The Scots pine seedlings were collected in early May 2011 from four reforested sites (Fig. 1). The 1-year-old bare-rooted seedlings were planted in mid-April and had not been treated with insecticide. All seedlings were collected during the period of weevil maturation feeding (typically on the bark of seedlings stems) and were living specimens with green-yellow needles. The areas damaged by weevils were located on the main stems and reached to the xylem of seedlings. Scots pine seedlings damaged by weevils were cut with a sterile secateur and placed in separate, clean paper bags. Then, seedlings were stored for a maximum of $48 \mathrm{~h}$ in a cool room at $4{ }^{\circ} \mathrm{C}$ until they were used for the isolation of fungi. Wound samples were cut into 6-cm-long sections and surface-disinfected by immersion in $95 \%$ ethyl alcohol. After drying, small pieces of wounds (approximately $5 \times 5 \mathrm{~mm}$ ) were removed from each wound section (six pieces per one wound) and placed in Petri dishes containing CMEA medium. Altogether, 1,392 samples of wounds were collected in this study. Fragments were taken from a total of 232 seedlings damaged by $H$. abietis (28-93 seedlings/site).

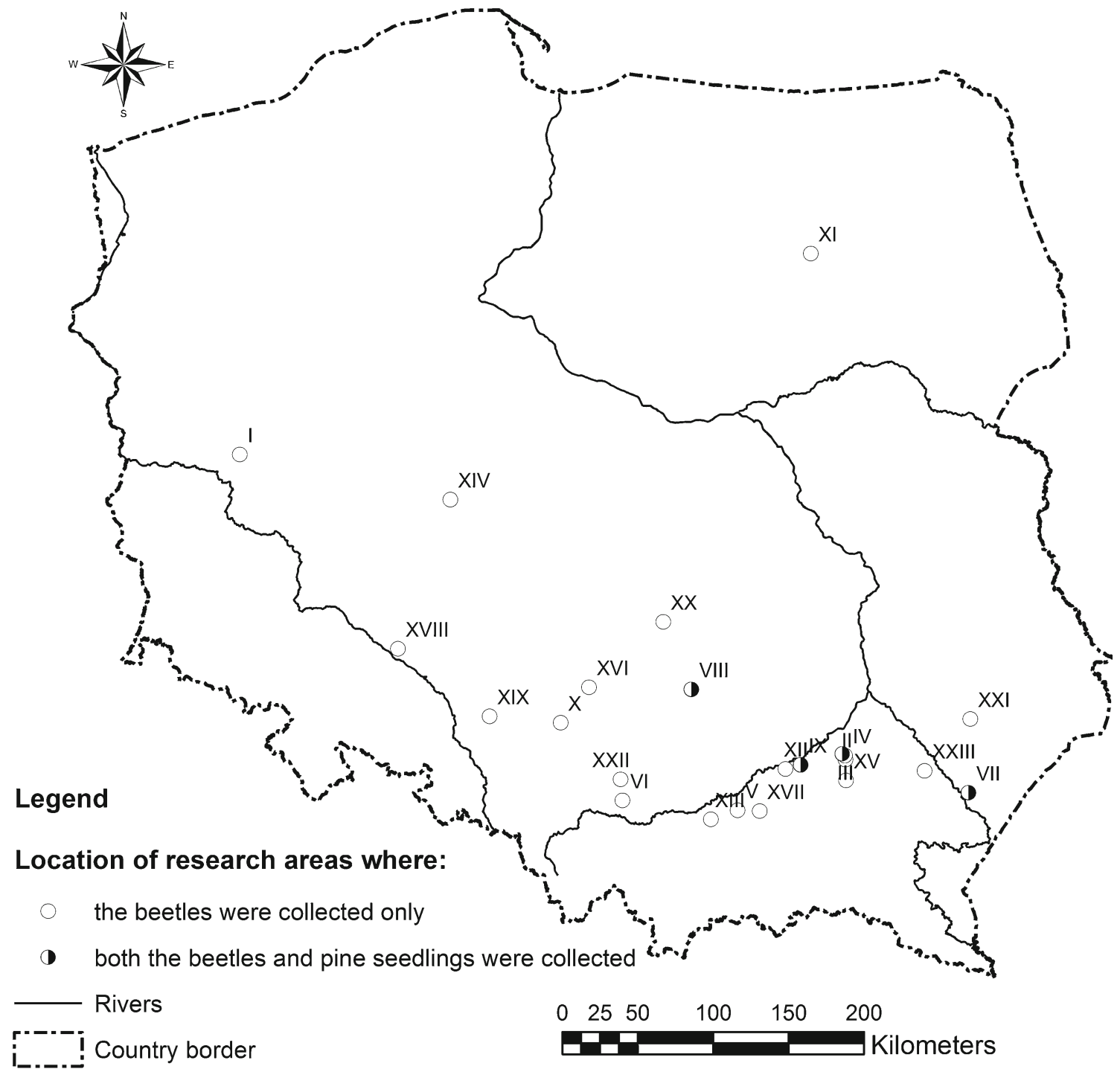

Fig. 1 Location of sites where adults of $H$. abietis and seedlings damaged by insects were collected: I Babimost, II Pateraki, III Czajkowa 1, IV Czajkowa 2, V Dąbrowa Tarnowska, VI Dulowa, VII Jarosław, VIII Jędrzejów, IX Szczurowa, $X$ Koszęcin, XI Myszyniec,

XII Lubasz, XIII Stanisławice, XIV Taczanów, XV Tuszyma, XVI Złoty Potok, XVII Wierzchosławice, XVIII Oława, XIX Strzelce Opolskie, $X X$ Przedbórz, XXI Biłgoraj 
2.2 Culture procedures, fungal identification and sequences analyses

All isolations were made on $2 \%$ CMEA medium. When necessary, the cultures were purified by transferring small pieces of mycelium or spore masses from individual colonies to fresh $2 \%$ MEA. The cultures were incubated at room temperature in the dark. Purified cultures were grouped according to culture morphology using a Nikon Eclipse $50 i$ microscope (Nicon ${ }^{\circledR}$ Corporation, Tokyo, Japan) and an Invenio $5 \mathrm{~S}$ digital camera (DeltaPix ${ }^{\circledR}$, Maalov, Denmark) with the Coolview 1.6.0 software (Precoptic ${ }^{\circledR}$, Warsaw, Poland). Fungal structures (conidiophores, conidia) and colony characteristics were compared with the descriptions of species given in the literature (de Hoog 1974; Jacobs and Wingfield 2001; Kim et al. 2005; Linnakoski et al. 2010; Roets et al. 2008; Upadhyay 1981). Isolates were selected for DNA sequencing from each morphological group, and these cultures were deposited in the Culture Collection of Fungi of the Laboratory of Department of Forest Pathology, Hugo Kołłataj University of Agriculture, Cracow, Poland.

DNA was extracted using the PrepMan Ultra Sample preparation reagent (Applied Biosystems, Foster City, CA, USA) using the manufacturer's protocol. The ITS rDNA region (ITS1-5.8S-ITS2) was amplified using the primers ITS 1F (Gardes and Bruns 1993) and ITS 4 (White et al. 1990). Part of the $\beta$-tubulin gene region was amplified using primers Bt2a and Bt2b (Glass and Donaldson 1995). Gene fragments were amplified in a $25-\mu \mathrm{L}$ reaction mixture containing $0.25 \mu \mathrm{L}$ of Phusion High-Fidelity DNA polymerase (Finnzymes, Espoo, Finland), $5 \mu \mathrm{L}$ Phusion HF buffer $(5 \times)$, $0.5 \mu \mathrm{L}$ dNTPs $(10 \mathrm{mM}), 0.75 \mu \mathrm{L}$ DMSO $(100 \%)$ and $0.5 \mu \mathrm{L}$ of each primer $(25 \mu \mathrm{M})$. The amplification reactions were performed using a Biometra T-Personal 48 Thermocycler (Biometra GmbH, Goettingen, Germany). The PCR conditions were an initial denaturation step at $98{ }^{\circ} \mathrm{C}$ for $30 \mathrm{~s}$ followed by 35 cycles of $5 \mathrm{~s}$ at $98^{\circ} \mathrm{C}, 10 \mathrm{~s}$ at $57{ }^{\circ} \mathrm{C}$ and $30 \mathrm{~s}$ at $72{ }^{\circ} \mathrm{C}$, and a final chain elongation at $72{ }^{\circ} \mathrm{C}$ for $8 \mathrm{~min}$. The PCR products were visualised under UV light on a $2 \%$ agarose gel stained with ethidium bromide. Amplified products were sequenced with the BigDye Terminator v3.1 Cycle Sequencing Kit (Applied Biosystems, Foster City, CA, USA) using the same primers that were used for the PCR reaction. Sequences (Table 1) were compared with the data from GenBank using a BLAST similarity search. All sequences were aligned online with MAFFT v6 (Katoh and Toh 2008), using the E-INS-i option with a gap opening penalty of 1.53 and an offset value of 0.00 .

Datasets were analysed using maximum likelihood (ML) and Bayesian inference (BI). For ML and Bayesian analyses, the best-fit substitution models for each data set were established using the corrected Akaike information criterion in jModelTest 0.1.1 (Posada 2008). The selected model for the ITS was GTR $+\mathrm{I}+\mathrm{G}$; for the $\beta$-tubulin gene, it was $\operatorname{TrN}+\mathrm{G}$ (Grosmannia/Leptographium and Ophiostoma piceae and Ophiostoma minus complexes), GTR $+\mathrm{G}$ (Sporothrix schenckii-Ophiostoma stenoceras complex). ML searches were conducted in PhyML 3.0 (Guindon et al. 2010), via the Montpelier online server (http://www.atgc-montpellier.fr/ phyml/) with 1,000 bootstrap replicates. BI analyses based on a Markov Chain Monte Carlo (MCMC) were performed with MrBayes v3.1.2 (Ronquist and Huelsenbeck 2003). The MCMC chains were run for ten million generations using the best fitting model. Trees were sampled every 100 generations, resulting in 100,000 trees from both runs. The burn-in value for each dataset was determined in Tracer v1.4.1 (Rambaut and Drummond 2007).

All sequences generated in this study were deposited in the NCBI GenBank (Table 1) and are presented in the phylogenetic tree (Fig. 2).

\subsection{Statistical analyses}

The Simpson diversity index (Simpson 1949) was used to indicate fungal diversity. The index is defined as:

$D=1-\sum_{i=1}^{i=s} p_{i}^{2}$

where $P_{i}$ is the probability of sampling a species, $i$ is the frequency of species $i /$ total frequency for all species and $S$ is species richness, the number of species per sample. The Shannon-Weaver diversity index was also used to compare the diversity of fungal taxa of $H$. abietis from different sites. This index, $H=-\sum\left(P_{i} \times \ln P_{i}\right)$, combines measurements of richness with those of evenness, so that rare species carry less weight. $P_{i}$ is the proportion of the total sample represented by species $i$ (Hill et al. 2003). Evenness (E), a measure of the relative abundance of species, is expressed as $E=H / H_{\max }$, where $H_{\max }=-\ln (S)$. Fungal dominance was determined by Camargo's (1993) index $(1 / S)$, where $S$ represents species richness. A species was defined as dominant if $P_{i}>1 / S$.

\section{Results}

\subsection{Identification of ophiostomatoid species}

Ophiostomatoid fungi were recovered from $86 \%$ of the adult weevils and from $90 \%$ of the seedlings. The isolations from adults of $H$. abietis and pine seedling yielded a total of 1,564 fungal isolates. Morphological investigation showed that 16 ophiostomatoid groups that produced Leptographium, Pesotum, Hyalorhinocladiella and Sporothrix anamorph structures in culture were collected. Four groups presented 
Table 1 Cultures used in this study and GenBank accession numbers for sequences

\begin{tabular}{|c|c|c|c|c|}
\hline \multirow[t]{2}{*}{ Fungi } & \multirow[t]{2}{*}{ Strain } & \multirow[t]{2}{*}{ Site } & \multicolumn{2}{|c|}{ GenBank accession no. } \\
\hline & & & ITS rDNA & $\beta$-Tubulin \\
\hline \multirow[t]{3}{*}{ Leptographium procerum } & 630RJ & Jarosław & JX028559 & JX046803 \\
\hline & $18 \mathrm{RJ}$ & Jędrzejów & JX028560 & \\
\hline & 434RJ & Myszyniec & JX028561 & \\
\hline \multirow[t]{2}{*}{ Leptographium lundbergii } & $603 \mathrm{RJ}$ & Dulowa & JX028557 & \\
\hline & $593 \mathrm{RJ}$ & Dulowa & JX028558 & JX046802 \\
\hline \multirow[t]{2}{*}{ Leptographium truncatum } & $585 \mathrm{aRJ}$ & Dulowa & JX028562 & \\
\hline & $721 \mathrm{RJ}$ & Jędrzejów & JX028563 & JX046804 \\
\hline \multirow[t]{2}{*}{ Pesotum fragrans } & $619 \mathrm{aRJ}$ & Jarosław & JX028587 & \\
\hline & 770RJ & Czajkowa I & JX028588 & JX046816 \\
\hline Ophiostoma piliferum & 739RJ & Stanisławice & JX028573 & JX046811 \\
\hline \multirow[t]{9}{*}{ Ophiostoma quercus } & $2 \mathrm{RJ}$ & Jędrzejów & JX028574 & \\
\hline & $626 \mathrm{RJ}$ & Jarosław & JX028575 & \\
\hline & $619 \mathrm{bRJ}$ & Jarosław & JX028576 & JX046813 \\
\hline & 278RJ & Dąbrowa Tarnowska & JX028580 & \\
\hline & $777 \mathrm{RJ}$ & Czajkowa II & JX028577 & \\
\hline & 749RJ & Taczanów & JX028581 & \\
\hline & $534 \mathrm{pRJ}$ & Czajkowa I & JX028578 & \\
\hline & $597 \mathrm{aRJ}$ & Dulowa & JX028579 & \\
\hline & $624 \mathrm{RJ}$ & Jarosław & & JX046812 \\
\hline \multirow[t]{5}{*}{ Ophiostoma piceae } & $686 \mathrm{RJ}$ & Złoty Potok & JX028569 & \\
\hline & 989pRJ & Jędrzejów & JX028571 & \\
\hline & $601 \mathrm{RJ}$ & Jarosław & & JX046810 \\
\hline & $28 \mathrm{RJ}$ & Jędrzejów & JX028570 & \\
\hline & $442 \mathrm{RJ}$ & Myszyniec & JX028572 & JX046809 \\
\hline \multirow[t]{2}{*}{ Ophiostoma floccosum } & $682 \mathrm{RJ}$ & Złoty Potok & JX028566 & JX046806 \\
\hline & $688 \mathrm{RJ}$ & Złoty Potok & JX028567 & \\
\hline \multirow[t]{2}{*}{ Ophiostoma minus } & $733 \mathrm{aRJ}$ & Stanisławice & JX028585 & \\
\hline & 734RJ & Stanisławice & JX028586 & JX046807 \\
\hline \multirow[t]{3}{*}{ Grosmannia radiaticola } & $535 \mathrm{RJ}$ & Koszęcin & JX028554 & JX046800 \\
\hline & $585 \mathrm{bRJ}$ & Dulowa & JX028556 & JX046801 \\
\hline & 597bRJ & Dulowa & JX028555 & \\
\hline \multirow[t]{2}{*}{ Sporothrix inflata } & $581 \mathrm{RJ}$ & Koszęcin & JX028589 & \\
\hline & $577 \mathrm{aRJ}$ & Koszęcin & JX028590 & JX046817 \\
\hline \multirow[t]{2}{*}{ Ophiostoma cf. abietinum } & 764RJ & Czajkowa II & JX028564 & JX046805 \\
\hline & $673 \mathrm{pRJ}$ & Jędrzejów & JX028565 & \\
\hline Ophiostoma sp. & $479 \mathrm{RJ}$ & Czajkowa I & JX028582 & JX046814 \\
\hline Sporothrix variecibatus & $577 \mathrm{bRJ}$ & Koszęcin & JX028591 & JX046818 \\
\hline \multirow[t]{2}{*}{ Ophiostoma stenoceras } & $986 \mathrm{pRJ}$ & Jędrzejów & JX028584 & JX046815 \\
\hline & $968 \mathrm{pRJ}$ & Jędrzejów & JX028583 & \\
\hline Ophiostoma pallidulum & 767RJ & Czajkowa II & JX028568 & JX046808 \\
\hline
\end{tabular}

Leptographium-like anamorphs while 12 groups formed Pesotum, Hyalorhinocladiella and Sporothrix anamorphs (Tables 2 and 3).

The PCR resulted in fragments of $320-1,145 \mathrm{bp}$ for the ITS region and 222-489 bp for the $\beta$-tubulin gene regions in the subset of isolates sequenced. Further analyses of the ITS and $\beta$-tubulin sequences confirmed that the 15 morphological groups could be separated into two distinct phylogenetic groups within the Ophiostomatales. Groups with Leptographium-like anamorphs were related to Grosmannia and/or Leptographium species, while the remaining groups correspond well to species of Ophiostoma. However, Pesotum fragrans (Math.-Käärik) G. Okada \& Seifert with Pesotum anamorph formed a 


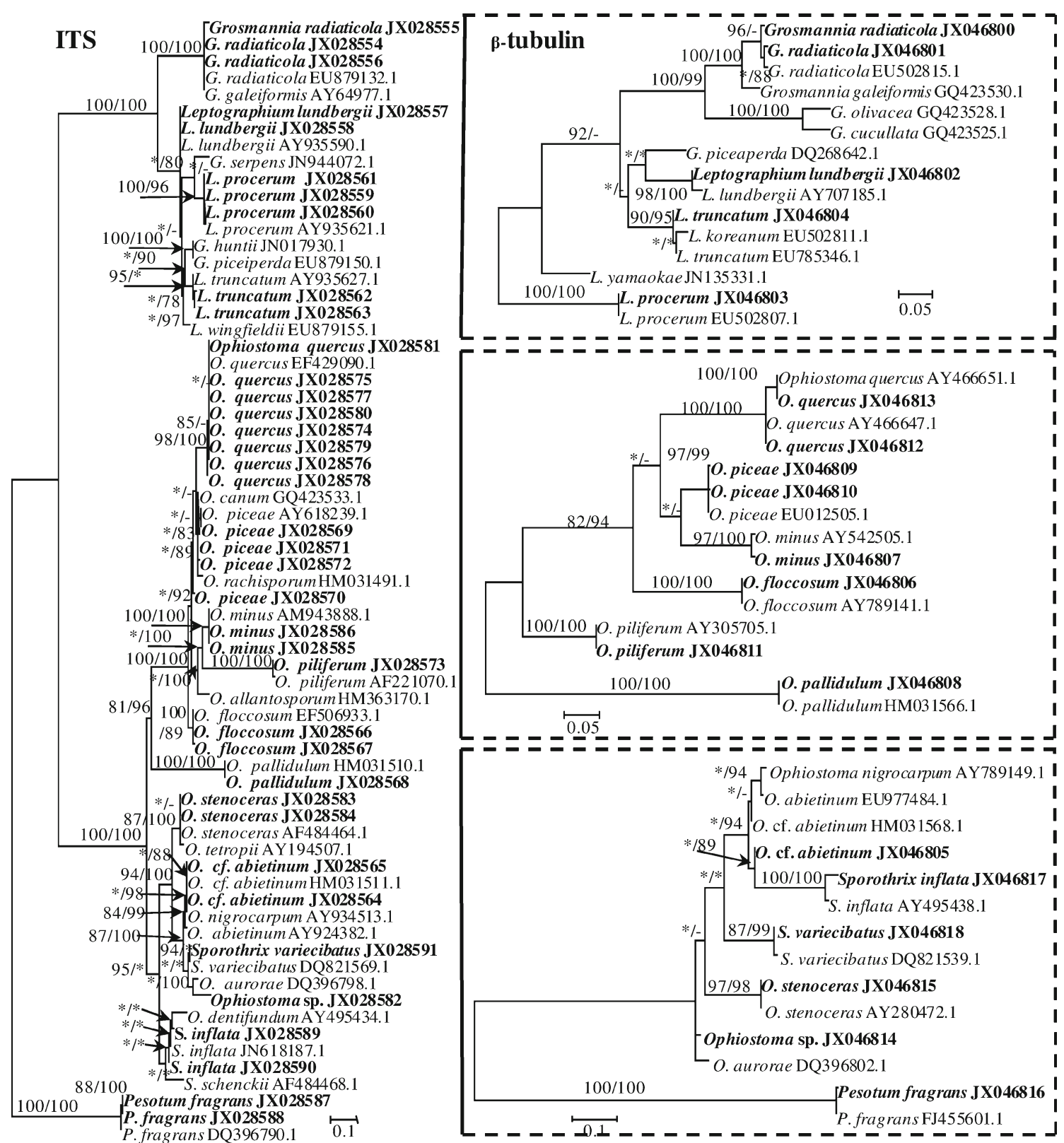

Fig. 2 Phylograms obtained from analyses of ITS sequence data, revealing the identity of ophiostomatoid fungi isolated from $H$. abietis infesting pine forests in Poland. Phylograms of partial $\beta$-tubulin data are shown for species groups where ITS sequences did not resolve the identity of Polish isolates. The $\beta$-tubulin data sets were analysed separately from each other because of differences among the three groups in the presence and absence of introns 3, 4 and 5. Sequences obtained during this study are presented in bold type. All phylograms presented were obtained from maximum likelihood (ML) analyses. Bootstrap values $>75 \%$ for $\mathrm{ML}$ and posterior probabilities $>75 \%$ obtained from Bayesian (BI) analyses are presented at nodes as follows: $\mathrm{ML} / \mathrm{BI}$ distinct third lineage in the Ophiostomatales (Fig. 2). The ITS and $\beta$-tubulin data confirmed that groups with Leptographium-like anamorphs represented four species, including Grosmannia radiaticola (J.J. Kim, Seifert \& G.H. Kim) Zipfel, Z.W. de Beer \& M.J. Wingf., Leptographium lundbergii Lagerb. \& Melin, L. procerum and Leptographium truncatum (M.J. Wingf. \& Marasas) M.J. Wingf. Groups with affinity to the genus Ophiostoma represented ten known species (Ophiostoma cf. abietinum
(Peck) M.J. Wingf.; Ophiostoma floccosum Math.-Käärik; O. minus (Hedgc.) Syd. \& P. Syd.; Ophiostoma pallidulum Linnakoski, Z.W. de Beer \& M.J. Wingf.; O. piceae (Münch) Syd. \& P. Syd.; O. piliferum; Ophiostoma quercus (Georgev.) Nannf.; O. stenoceras (Robak) Nanf.; Sporothrix inflata de Hoog 1974; Sporothrix variecibatus Roets, Z.W. de Beer \& Crous and one unknown species named here as Ophiostoma $\mathrm{sp}$. The isolate of Ophiostoma sp. produced Sporothrix anamorph in culture, and in phylogenetic analyses, it was most 


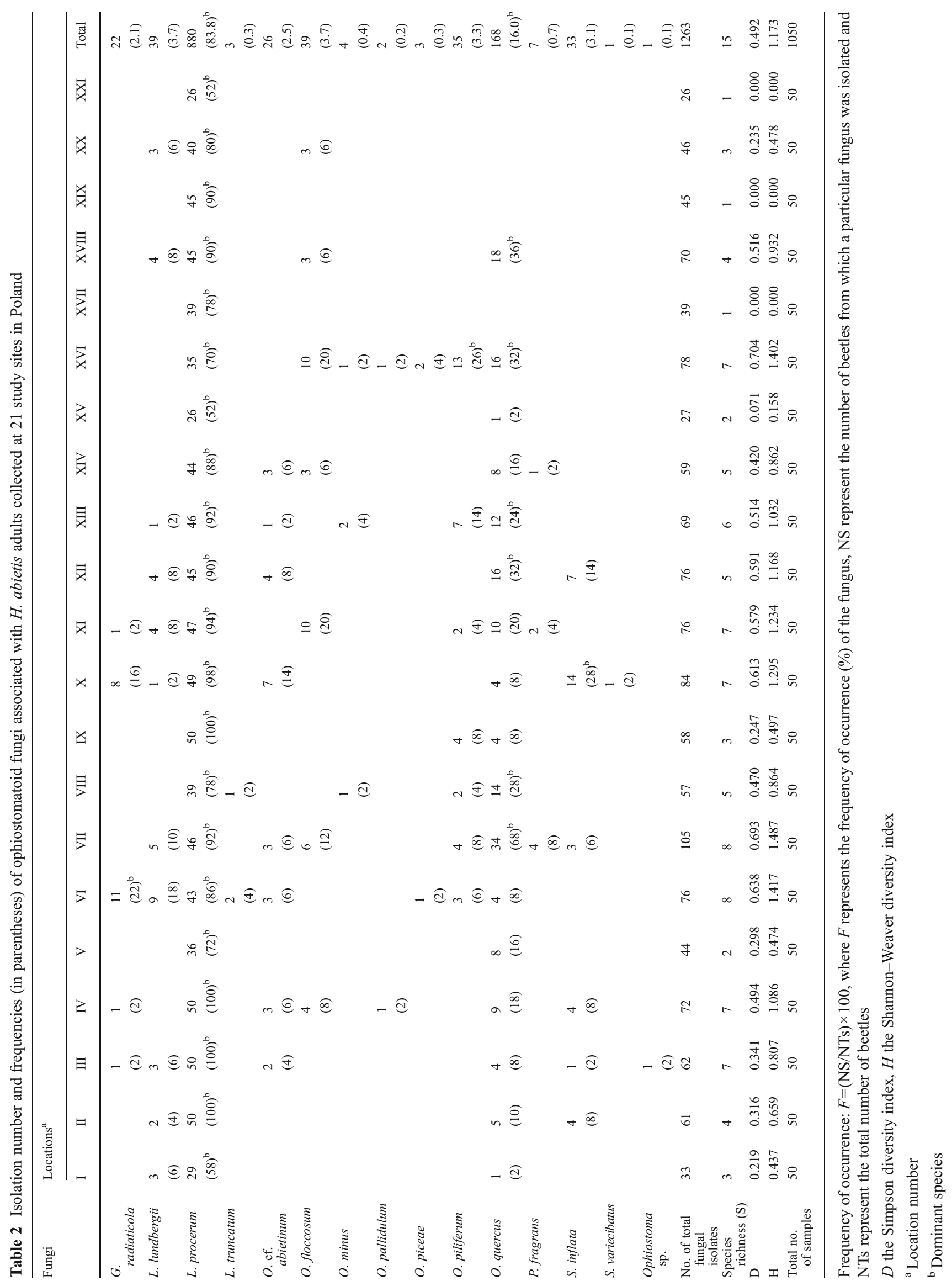


Table 3 Isolation number and frequencies (in parentheses) of ophiostomatoid fungi isolated from seedlings attacked by $H$. abietis

Percentages given in parentheses were calculated as no. of individual seedlings colonising by the respective fungus/total number of seedlings $) \times 100$

\begin{tabular}{llllll}
\hline Fungi & \multicolumn{2}{l}{ Locations } & & & \\
\cline { 2 - 5 } & III & VII & VIII & IX & Total \\
\hline $\begin{array}{l}\text { Leptographium procerum } \\
\text { Ophiostoma floccosum }\end{array}$ & $85(91.4)$ & $28(100.0)$ & $68(98.5)$ & $24(57.1)$ & $205(88.4)$ \\
$\begin{array}{l}\text { Ophiostoma piceae } \\
\text { Ophiostoma quercus }\end{array}$ & $16(1.2)$ & & & $1(2.4)$ & $3(1.3)$ \\
$\begin{array}{l}\text { Ophiostoma stenoceras } \\
\text { Sporothrix inflata }\end{array}$ & $2(0.2)$ & $2(7.1)$ & $1(1.4)$ & $5(11.9)$ & $24(10.3)$ \\
$\begin{array}{l}\text { Sporothrix variecibatus } \\
\text { Ophiostoma cf. abietinum }\end{array}$ & $51(54.8)$ & $1(3.6)$ & $5(7.2)$ & $3(7.1)$ & $60(25.7)$ \\
Total no. of isolates & 157 & & & $1(2.4)$ & $1(0.4)$ \\
Number of seedlings $(\%)$ & 93 & 31 & 77 & & $1(0.4)$ \\
\hline
\end{tabular}

closely related to Ophiostoma aurorae X.D. Zhou \& M.J. Wingf. (Fig. 2).

\subsection{Fungal isolation from H. abietis beetles}

From the crushed adults of $H$. abietis, we obtained 1,263 isolates comprising 15 species (Table 2). The most dominant species was $L$. procerum, which was isolated with an average isolation frequency of $84 \%$. This species was dominant at all sites and was isolated from every beetle sampled at four sites (Pateraki, Czajkowa I, Czajkowa II, Szczurowa). The second-most dominant isolate was the $O$. quercus, which was isolated from $16 \%$ of the beetles (from $0 \%$ at Wierzchosławice, Strzelce Opolskie, Przedbórz and Biłgoraj to $68 \%$ at Jarosław). In contrast to $L$. procerum, $O$. quercus was dominant at six sites (Table 2). Other species were isolated only rarely. Among these, four species, L. lundbergii, O. floccosum, O. piliferum and $S$. inflata, were isolated above $3 \%$ of the time. However, O. piliferum, $S$. inflata and G. radiaticola dominated one site each. L. truncatum $O$. cf. abietinum, $O$. pallidulum, O. minus, O. piceae, $P$. fragrans and $S$. variecibatus were found occasionally (Table 2).

The fungal biodiversity and species-richness values varied among the 21 sites (Table 2). The fungal community associated with $H$. abietis in Jarosław, Dulowa and Złoty Potok had the highest biodiversity $(D>0.64 ; H>1.4)$ and speciesrichness values (Jarosław - eight species, Dulowa and Złoty Potok - seven species). The lowest biodiversity and species richness were found in Wierzchosławice, Strzelce Opolskie and Biłgoraj ( $D, H=0 ; S=1$ species) (Table 2).

\subsection{Fungal isolation from seedlings damaged by $H$. abietis}

A total of 301 fungal isolates were obtained from the 232 live seedlings sampled in this study. Eight ophiostomatoid species were isolated: $L$. procerum, $O$. cf. abietinum, $O$. floccosum, $O$. piceae, O. quercus, O. stenoceras, $S$. inflata and $S$. variecibatus (Table 3). L. procerum was isolated most frequently and was found in $88 \%$ of the seedlings (ranging from $57 \%$ at Szczurowa to $100 \%$ at Jarosław). S. inflata was isolated from $26 \%$ (4 \% at Jarosław to $55 \%$ at Czajkowa 1), while $O$. quercus was isolated from $10 \%$ (1\% at Jędrzejów to $17 \%$ Czajkowa I) of the seedlings. The remaining species were isolated less frequently (Table 3).

\section{Discussion}

This survey of adult beetles showed that ophiostomatoid species were vectored by $H$. abietis in pine stands in Poland. This association was also confirmed by the isolation of these fungi from pine seedlings during the maturation feeding of $H$. abietis. In this study, in which identification was based on morphological characteristics and DNA comparisons, 16 species of ophiostomatoid fungi (including Grosmannia, Ophiostoma, Leptographium, Pesotum and Sporothrix spp.) were isolated from the beetles. The most commonly encountered fungal associates of $H$. abietis were L. procerum and $O$. quercus.

The results of this study show that the fungal diversity associated with $\mathrm{H}$. abietis in Poland is significantly greater than the diversity that was previously recognised in France (Piou 1993). In France, H. abietis beetles were only found to be associated with $L$. procerum, $L$. wingfieldii, $O$. canum and $O$. piliferum, while we isolated 14 additional ophiostomatoid species that had not previously been reported in association with $H$. abietis. We did not isolate $L$. wingfieldii and $O$. canum, which were found in the French study. However, the first species is very rarely detected in Poland (Jankowiak 2006a), although O. canum is a common associate of Tomicus spp. in Poland (Jankowiak 2008) and in 
other parts of Europe (Kirisits 2004; Linnakoski et al. 2012a). A similarly high fungal diversity has been recently described for $H$. pales on $P$. palustris in Georgia (Zanzot et al. 2010). These authors found that L. procerum, L. terebrantis, L. serpens, G. huntii, O. ips-like, Ophiostoma spp. and Pesotum spp. were associated with $H$. pales.

Due to the biology of $H$. abietis, the majority of ophiostomatoid species vectored by this weevil represent species regarded as soil-borne fungi (e.g., S. inflata) or as associates of root-feeding bark beetles (e.g. Leptographium spp.). In contrast to bark beetles, the $H$. abietis adults remain active for 2 to 3 years, their feeding occurs on the stems and twigs of seedlings or on roots of trees and the adults spend most of their lives on the ground (Nordenhem 1989). In view of these differences, an important question can be raised: How constant and specific are the symbiotic relationship of ophiostomatoid fungi with this weevil? We consider $H$. abietis to be intimately associated with ophiostomatoid fungi, in particular with Leptographium spp. The fact that spores of fungi carried by the adults of $H$. abietis are probably protected by secretions of the pronotal grandular apparatus (Lévieux et al. 1994) supports this view. Additionally, the majority of ophiostomatoid fungi, which were found on adults of $H$. abietis in this study, were also isolated from the galleries of $H$. abietis (Jankowiak and Bilański, unpublished data).

Consistent with the findings of Piou (1993), the most commonly encountered fungal associate of $H$. abietis was L. procerum. This fungus was isolated from the adults with very high frequency and was dominant at all sites, suggesting a specific relationship. The association of $L$. procerum with $H$. abietis found in this study was not surprising because this fungus is known to be a coloniser of conifer roots (Barnard et al. 1991; Eckhardt et al. 2007; Otrosina et al. 1999) and an associate of pine-infesting bark beetles (Kirisits 2004; Linnakoski et al. 2012b). L. procerum is likely the species in the genus Leptographium that occurs most frequently on Scots pine in Poland. To date, this fungus has been recorded in Poland in association with Tomicus spp. (Jankowiak 2006a, 2008), Ips sexdentatus (Börn.) (Jankowiak 2012), Trypodendron lineatum (Oliv.), Hylastes ssp., Hylurgus ligniperda (Fabr.) (Jankowiak and Kolařík, unpublished data) and cerambycid beetles (Jankowiak and Rossa 2007). Recently, Jankowiak et al. (2012) also reported L. procerum as a common coloniser of pine roots in Poland.

The frequency of $O$. quercus on $H$. abietis adults was unexpectedly high; this fungus dominated the fungal community of weevils in some sites. According to Harrington et al. (2001), O. piceae is most often isolated from conifer tree hosts, while $O$. quercus mostly colonises tissues of hardwood trees. However, recent studies have shown that $O$. quercus is much more widely distributed on woody substrates than had previously been recognised. The fungus has been reported on pine plantations (Reay et al. 2005; Thwaites et al. 2005; Zhou et al. 2006). O. piceae has been indentified in Poland in several earlier studies (Jankowiak 2006a, 2008) that were based only on morphology. However, the DNA sequence comparisons used in this study suggest that $O$. quercus can be more widespread in Pinus sylvestris stands than $O$. piceae. Similar results have also been obtained for other species of bark beetles and weevils infesting P. sylvestris in Poland (Jankowiak 2012; Jankowiak and Bilański, unpublished data). Detailed ecological studies are needed to define the host range for $O$. quercus and $O$. piceae.

In contrast to $O$. quercus, the presence of $S$. inflata on $H$. abietis adults was expected because this fungus is frequently isolated from soil and the other substrates associated with soil environments (de Hoog 1974). Recently, S. inflata was also isolated from the roots of dying and dead young Scots pine in Poland (Jankowiak et al. 2012). This study indicates that $H$. abietis, in addition to being a vector for $L$. procerum and $O$. quercus, is also a carrier of the soil-borne fungus $S$. inflata.

Similarly, L. lundbergii, O. floccosum and O. piliferum were also isolated from the adults of $H$. abietis at a relatively low and variable frequency. These fungi are known agents of blue stain on $P$. sylvestris, and they are also associated with pine-infesting bark beetles (Kirisits 2004; Linnakoski et al. 2012a, b). L. lundbergii, for example, is commonly associated with root-feeding beetles (Hylastes spp. and $H$. ligniperda; Jankowiak and Bilański, unpublished data) and Hylurgops palliatus (Gyll.) (Jankowiak 2006b), while $O$. floccosum was found in association with I. sexdentatus in Poland (Jankowiak 2012). These fungi seem to occur as infrequent associates of $H$. abietis. The results of this study also showed that similar ecological areas may contain $O$. cf. abietinum, which was found at a low frequency in the present work. It was also recently recorded in association with Tomicus minor (Hart.) in Russia (Linnakoski et al. 2010) and with I. sexdentatus in Poland (Jankowiak 2012).

Another species found in the present study was G. radiaticola (anamorph Pesotum pini (L.J. Hutchison \& J. Reid) G. Okada \& Seifert). This fungus was originally described on Pinus radiata D. Don. in New Zealand (Kim et al. 2005) with Leptographium-like anamorph. In our study, isolates of $G$. radiaticola produced a similar type of conidial structures in culture, but none of these isolates produced teleomorphs, even with mating and the addition of wooden blocks to the medium. This species is morphologically and phylogenetically similar to Grosmannia galeiformis (B.K. Bakshi) Zipfel, Z.W. de Beer \& M.J. Wingf. (Kim et al. 2005), which is a relatively well-known species in Scandinavia and others parts of Europe (Bakshi 1951; MathiesenKäärik 1953; Zhou et al. 2004). According to Kim et al. 
(2005), G. radiaticola is heterothallic with two mating types, but G. galeiformis appeared to be homothallic. Zhou et al. (2004) provided evidence that G. galeiformis is heterothallic, although some of their isolates were also homothallic. G. radiaticola can be distinguished from $G$. galeiformis only by the sizes of the ascospores (Kim et al. 2005). The ITS sequences of these species are very similar, but their $\beta$-tubulin sequences differ substantially (Fig. 2). Despite these differences, the taxonomic status of both species remains unclear, especially given that Thwaites et al. (2005) considered G. radiaticola to be the same species as G. galeiformis. Up to the present study, G. radiaticola was known only outside Europe. However, recently published data using $\beta$-tubulin and EF $1-\alpha$ genes for fungal identification show that $G$. radiaticola is distributed throughout Europe and in other continents, while the $G$. galeiformis occurs only in association with Hylastes brunneus Erchison, H. palliatus Gyll. and T. lineatum in northern Europe (Linnakoski et al. 2012b). DNA sequence comparisons for two gene regions of isolates obtained from $H$. abietis confirmed that $G$. radiaticola occurs in Europe. This study represents the first reports of G. radiaticola from central Europe and from Scots pine.

Although it has been recovered only rarely from the $H$. abietis and infested pine seedlings, S. variecibatus was found in the present study. This fungus has previously been described by Roets et al. (2008), where it was found in South African mites occurring in Protea spp. infructescences and Eucalyptus leaf litter. It has also been detected as a dominant fungal species in a mixed microbial culture obtained from activated petrochemical refinery sludge (Rene et al. 2010), soil in Spain and Eucalyptus tree cankers in Australia (de Beer, personal communication). Our study has shown that $S$. variecibatus also occurs in pine forest habitats, suggesting that the species may be distributed throughout the world.

The ecology of $O$. pallidulum, which was occasionally isolated from adult $H$. abietis in this study, is poorly understood. This species has been described by Linnakoski et al. (2010), who isolated it from several different bark beetles infesting pine and spruce trees in Finland, where it was found mainly in association with H. brunneus. Recently, O. pallidulum was also isolated from the roots of dying and dead young Scots pine in Poland (Jankowiak et al. 2012). This may indicate that $O$. pallidulum is closely associated with the soil environment.

The other four ophiostomatoid species, O. minus, $L$. truncatum, P. fragrans and Ophiostoma sp., were isolated at very low frequencies from adults of $H$. abietis. The very low frequency of $O$. minus occurrence was surprising because it causes blue stain on pine timber and is a very common associate of various pine-infesting bark beetles in Europe (Kirisits 2004; Linnakoski et al. 2012a). The lower frequency of $O$. minus on beetles could be due to its ecological niches. It appears to be specifically associated mainly with the Tomicus spp. that infest middle and upper parts of trees in Poland (Jankowiak 2006a, 2008). In contrast to Tomicus spp., H. abietis beetles lives mainly on the ground of the forest (Hylobius hibernates in the upper layers of the soil). Another species, P. fragrans, has been occasionally collected from several bark beetles in Europe (Kirisits 2004; Linnakoski et al. 2012a; Romón et al. 2007). It has been reported in only one study in Poland. Jankowiak and Kolarik (2010) isolated the species from galleries of Cryphalus piceae (Ratz.) on Abies alba Mill. L. truncatum was detected for the first time in Poland in this study. In Europe, this species is associated with root-feeding bark beetles on Scots pine (Gibbs and Inman 1991; Linnakoski 2011; Linnakoski et al. 2012b; Wingfield and Gibbs 1991).

In this study, the species spectrum and frequency of fungal associates of $\mathrm{H}$. abietis differed from site to site. This variation in fungal population composition is wellknown from the literature and could be due to many different factors (Linnakoski et al. 2012a). The geographical and climatic differences seem to be a main factor that affects the assemblages of fungi. Other factors that could be important include sampling and isolation methodology. However, despite application of the same sampling and isolation methods and the similar characteristics of sampling sites (e.g. the same reforestation technology) in this study, the fungal communities differed among sites. We suspect that geographical variation, different environmental conditions (temperature, humidity) and microsites (degree of sunlight trap logs) could have the largest influence on the fungi associated with $H$. abietis.

The results show a strong relationship between fungi transported by $H$. abietis adults and the presence of these fungi in pine seedlings. All of the fungal species isolated from seedlings (except $O$. stenoceras) were also found on adult weevils, suggesting that $H$. abietis very effectively introduces the ophiostomatoid species into the fresh tissues of pine seedlings during maturation feeding. This pattern is similar to the scenario described by Reay et al. $(2002,2005)$ for $P$. radiata seedlings damaged by Hylastes ater Payk. As in the results obtained from our adult weevils, L. procerum was the most frequently isolated species from seedlings ( $88 \%)$. This finding is also in agreement with the results of Piou (1993), although he found $L$. procerum on only $18 \%$ of seedlings. The different health conditions of pine seedlings in each study might have affected the species found. In this work, live pine seedlings were used for the fungal isolations, while in previous studies the seedlings were dead. We also isolated fungi from dead seedlings, but we did not detect the ophiostomatoid species in these seedlings. For this reason, Piou (1993) probably did not find other ophiostomatoid species in seedlings. In contrast to the 
results from adults of $H$. abietis, $S$. inflata was isolated more frequently than $O$. quercus from seedlings. As a soil-borne fungus, $S$. inflata might also infect seedlings from the surrounding soil following damage caused by $H$. abietis. According to Piou (1993), the presence of L. procerum in seedlings damaged by $H$. abietis could increase the mortality of seedlings damaged by weevil feeding. A similar relationship between the severity of $H$. ater feeding damage and the presence and number of species of Ophiostoma were also noted by Reay et al. (2005) in New Zealand.

In conclusion, in contrast to previous studies, we show that considerably more diverse fungal species were associated with the large pine weevil. This study confirms that $L$. procerum is a common associate of $H$. abietis. O. quercus seems to also be a common associate of the pine weevil, but its frequency in different sites was variable. Other ophiostomatoid species were found inconsistently and in low numbers, indicating causal associations. All ophiostomatoid species recovered in this study (with the exception of $L$. procerum) had never before been isolated from $H$. abietis. This is also the first report of G. radiaticola in central Europe and L. truncatum and S. variecibatus in Poland. In this study, H. abietis also acted as an effective vector carrying ophiostomatoid species to $P$. sylvestris seedlings, especially in the cases of $L$. procerum and $S$. inflata.

Funding The work was supported by grants from the Polish Ministry of Education and Science NN309 049037.

\section{References}

Bakshi BK (1951) Studies on four species of Ceratocystis, with a discussion on fungi causing sapstain in Britain. Mycol Pap $35: 1-16$

Barnard EL, Gilly SP, Dixon WN (1991) Incidence of Heterobasidion annosum and other root-infecting fungi in residual stumps and roots in thinned slash pine plantations in Florida. Plant Dis 75:823-828

Camargo JA (1993) Must dominance increase with the number of subordinate species in competitive interactions? J Theor Biol $161: 537-542$

de Hoog GS (1974) The genera Blastobotrys, Sporothrix, Cladosporium and Calcarisporiella gen. nov. Stud Mycol 7:1-84

Eckhardt LG, Weber AM, Menard RD, Jones JP, Hess NJ (2007) Insect-fungal complex associated with loblolly pine decline in central Alabama. For Sci 53:84-92

Gardes M, Bruns TD (1993) ITS primers with enhanced specificity for basidiomycetes: application to the identification of mycorrhizae and rusts. Mol Ecol 2:113-118

Gibbs JN, Inman A (1991) The pine shoot beetle Tomicus piniperda as a vector of blue-stain fungi to windblown pine. Forestry 64:139249

Glass NL, Donaldson GC (1995) Development of primer sets designed for use with the PCR to amplify conserved genes from filamentous ascomycetes. Appl Environ Microbiol 61:1323-1330
Grégoire JC, Evans HF (2004) Damage and control of BAWBILT organisms, an overview. In: Lieutier F, Day KR, Battisti A, Grégoire JC, Evans HF (eds) Bark and wood boring insects in living trees in Europe, a synthesis. Kluwer, Dordrecht, pp 19-37

Guindon S, Dufayard JF, Lefort V, Anisimova M, Hordijk W, Gascuel O (2010) New algorithms and methods to estimate maximumlikelihood phylogenies: assessing the performance of PhyML 3.0. Syst Biol 59:307-321

Hanula JL, Meeker JR, Miller DR, Barnard EL (2002) Association of wildfire with tree health and numbers of pine bark beetles, reproduction weevils and their associates in Florida. For Ecol Manag 170:233-247

Harrington TC, McNew D, Steimel J, Hofstra D, Farrell R (2001) Phylogeny and taxonomy of the Ophiostoma piceae complex and the Dutch elm disease fungi. Mycologia 93:111-136

Hill TCJ, Kerry A, Walsh JA, Harris B, Moffett F (2003) Using ecological diversity measures with bacterial communities. FEMS Microbiol Ecol 43:1-11

Jacobs K, Wingfield MJ (2001) Leptographium species: tree pathogens, insect associates and agents of blue-stain. APS, St. Paul

Jacobs K, Wingfield MJ, Uzunovic A, Frisullo S (2001) Three new species of Leptographium from pine. Mycol Res 105:490-499

Jankowiak R (2006a) Fungi associated with Tomicus piniperda in Poland and assessment of their virulence using Scots pine seedlings. Ann For Sci 63:801-808

Jankowiak R (2006b) Mycobiota associated with Hylurgops palliatus (Gyll.) on Pinus sylvestris L. in Poland. Acta Soc Bot Pol 75:333338

Jankowiak R, Rossa R (2007) Filamentous fungi associated with Monochamus galloprovincialis and Acanthocinus aedilis (Coleoptera: Cerambycidae) in Scots pine. Pol Bot J 52:140-143

Jankowiak R (2008) Fungi associated with Tomicus minor on Pinus sylvestris in Poland and their succession into the sapwood of beetle-infested windblown trees. Can J For Res 38:2579-2588

Jankowiak R, Kolařík M (2010) Fungi associated with the fir bark beetle Cryphalus piceae in Poland. For Pathol 40:133-144

Jankowiak R (2012) Ophiostomatoid fungi associated with Ips sexdentatus on Pinus sylvestris in Poland. Dendrobiology 68:43-54

Jankowiak R, Bilański P, Kolařík M, Wasiuta D (2012) Rootcolonizing ophiostomatoid fungi associated with dying and dead young Scots pine in Poland. For Pathol. doi:10.1111/j.14390329.2012.00783.x

Kadlec Z, Starý P, Zumr V (1992) Field evidence for the large pine weevil. Hylobius abietis as a vector of Heterobasidion annosum. Eur J For Pathol 22:316-318

Katoh K, Toh H (2008) Recent developments in the MAFFT multiple sequence alignment program. Br Bioinforma 9:286-298

Kim J-J, Lim YW, Seifert KA, Kim SH, Breuil C, Kim GH (2005) Taxonomy of Ophiostoma radiaticola sp. nov. (Ophiostomatales, Ascomycetes), the teleomorph of Pesotum pini, isolated from logs of Pinus sylvestris. Mycotaxon 91:481-496

Kirisits T (2004) Fungal associates of European bark beetles with special emphasis on the ophiostomatoid fungi. In: Lieutier F, Day KR, Battisti A, Grégoire JC, Evans HF (eds) Bark and wood boring insects in living trees in Europe, a synthesis. Bark and wood boring insects in living trees in Europe, a synthesis. Kluwer, Dordrecht, pp 185-235

Klepzig KD, Raffa KF, Smalley EB (1991) Association of an insectfungal complex with red pine decline in Wisconsin. For Sci 37:1119-1139

Lévieux J, Piou D, Cassier P, André M, Guillaumin D (1994) Association of phytopathogenic fungi for the Scots pine (Pinus sylvestris L.) with the European pine weevil Hylobius abietis (L.) (Col. Curculionidae). Can Entomol 126:929-936

Linnakoski R (2011) Bark beetle-associated fungi in Fennoscandia with special emphasis on species of Ophiostoma and 
Grosmannia. Ph.D. dissertation, The Finnish Society of Forest Science, Joensuu, Finland

Linnakoski R, de Beer ZW, Ahtiainen J, Sidorov NP, Pappinen A, Wingfield MJ (2010) Ophiostoma spp. associated with pine- and spruce-infesting bark beetles in Finland and Russia. Persoonia 25:72-93

Linnakoski R, de Beer ZW, Niemelä P, Wingfield MJ (2012a) Associations of conifer-infesting bark beetles and fungi in Fennoscandia. Insects 3:200-227

Linnakoski R, de Beer ZW, Duong TA, Niemelä P, Pappinen A, Wingfield MJ (2012b) Grosmannia and Leptographium spp. associated with conifer-infesting bark beetles in Finland and Russia, including Leptographium taigense sp. nov. Antonie van Leewenhoek. doi:10.1007/s10482-012-9747-6

Livingston WH, Wingfield MJ (1982) First report of Verticicladiella procera on pines in Minnesota. Plant Dis 66:260-261

Mathiesen-Käärik A (1953) Eine Übersicht über die gewöhnlichsten mit Borkenkäfern assoziierten Bläuepilze in Schweden und einige für Schweden neue Bläuepilze. Meddn St Skogforsk 43:1-74

Nevill RJ, Alexander SA (1992) Root- and stem colonizing insects recovered from eastern white pines with Leptographium procerum root disease. Can J For Res 22:1712-1716

Nordenhem H (1989) Age, sexual development, and seasonal occurrence of the pine weevil Hylobius abietis (L.). J Appl Entomol 108:260-270

Örlander G, Nilsson U, Nordlander G (1997) Pine weevil abundance on clear-cuttings of different ages: a 6-year study using pitfall traps. Scand J For Res 12:225-240

Otrosina WJ, Bannwart D, Roncadori RW (1999) Root-infecting fungi associated with a decline of longleaf pine in the southeastern United States. Plant Soil 217:145-150

Pappinen A, von Weissenberg K (1994) Association of the pine-top weevil with Endocronartium pini on Scots pine. Eur J For Pathol 24:249-257

Pestaña M, Santolomazza-Carbone S (2010) Mutual benefit interactions between banded pine weevil Pissodes castaneus and bluestain fungus Leptographium serpens in maritime pine. Agric For Entomol 12:371-379

Piou D (1993) Rôle d'Hylobius abietis (L.) (Col, Curculionidae) dans le transport de Leptographium procerum (Kendr.) Wingf. Et son inoculation au Pin sylvestre. Ann Sci For 50:297-308

Posada D (2008) jModelTest: phylogenetic model averaging. Mol Biol Evolut 25:1253-1256

Rambaut A, Drummond AJ (2007) Tracer v1.4. Available from http:// beast.bio.ed.ac.uk/Tracer)

Reay SD, Walsh PJ, Ram A, Farrell RL (2002) The invasion of Pinus radiata seedlings by sapstain fungi, following attack by the black pine bark beetle, Hylastes ater (Coleoptera: Scolytidae). For Ecol Manag 165:47-56

Reay SD, Thwaites JM, Farrell RL (2005) A survey of Ophiostoma species vectored by Hylastes ater to pine seedlings in New Zealand. For Pathol 35:105-113

Rene ER, Veiga MC, Kennes C (2010) Biodegradation of gas-phase styrene using the fungus Sporothrix variecibatus: impact of pollutant load and transient operation. Chemosphere 79:221-227

Roets F, de Beer ZW, Wingfield MJ, Crous PW, Dreyer LL (2008) Ophiostoma gemellus and Sporothrix variecibatus from mites infesting Protea infructescences in South Africa. Mycologia $100: 496-510$

Romón P, Zhou X, Iturrondobeitia JC, Wingfield MJ, Goldarazena A (2007) Ophiostoma species (Ascomycetes: Ophiostomatales) associated with bark beetles (Coleoptera: Scolytidae) colonizing Pinus radiata in northern Spain. Can J Microbiol 53:756-767

Ronquist F, Huelsenbeck JP (2003) MrBayes 3: Bayesian phylogenetic inference under mixed models. Bioinformatics 19:1572-1574

Simpson EH (1949) Measurement of species diversity. Nature 163:688

Six DL (2003) Bark beetle-fungus symbiosis. In: Bourtzis K, Miller T A(eds) Insect symbiosis. CRC, Baton Rouge, pp 99-116

Six DL, Wingfield MJ (2011) The role of phytopathogenicity in bark beetle-fungus symbioses: a challenge to the classic paradigm. Annu Rev Entomol 56:255-272

Skrzecz I, Moore R (1997) The attractiveness of pine branches infected with selected wood colonising fungi to the large pine weevil (Hylobius abietis). USDA For Serv Gen Tech Rep NE-236:146-152

Tarwacki G (2011) Szeliniaki: sosnowiec i świerkowiec - Hylobius abietis L. i H. pinastri Gyll. In: Kolk et al (ed) Krótkoterminowa prognoza występowania ważniejszych szkodników i chorób infekcyjnych drzew leśnych w Polsce w 2011 roku. Instytut Badawczy Leśnictwa, Sękocin Stary, pp 32-33

Thwaites JM, Farrell RL, Duncan SM, Reay SD, Blanchette RA, Hadar E, Hadar Y, Harrington TC, McNew D (2005) Survey of potential sapstain fungi on Pinus radiata in New Zealand. N Z J Bot 43:653-663

Upadhyay HP (1981) A monograph of Ceratocystis and Ceratocystiopsis. The University of Georgia Press, Athens

Viiri H (2004) Fungi associated with Hylobius abietis and other weevils. In: Lieutier F, Day KR, Battisti A, Grégoire JC, Evans HF (eds) Bark and wood boring insects in living trees in Europe, a synthesis. Bark and wood boring insects in living trees in Europe, a synthesis. Kluwer, Dordrecht, pp 380-393

Wallertz K, Orlander G, Luoranen J (2005) Damage by pine weevil Hylobius abietis to conifer seedlings after shelterwood removal. Scand J For Res 20:412-420

White TJ, Bruns T, Lee S, Taylor J (1990) Amplification and direct sequencing of fungal ribosomal RNA genes for phylogenetics. In: Innis MA, Gelfand DH, Sninsky JJ, White TJ (eds) PCR protocols: a guide to methods and applications. Academic, San Diego, pp 315-322

Wingfield MJ (1983) Association of Verticicladiella procera and Leptographium terebrantis with insects in the Lake States. Can J For Res 13:1238-1245

Wingfield MJ, Gibbs JN (1991) Leptographium and Graphium species associated with pine-infesting bark beetles in England. Mycol Res 95:1257-1260

Wingfield MJ, Seifert KA, Webber JF (1993) Ceratocystis and Ophiostoma: taxonomy, ecology and pathogenicity. APS, St. Paul

Zanzot JW, Matusick G, Eckhardt LG (2010) Ecology of root-feeding beetles and their associated fungi on longleaf pine in Georgia. Environ Entomol 39:415-423

Zhou XD, de Beer ZW, Harrington TC, McNew D, Kirisits T, Wingfield MJ (2004) Epitypification of Ophiostoma galeiformis and phylogeny of species in the $O$. galeiformis complex. Mycologia 96:1329-1338

Zhou XD, de Beer ZW, Wingfield MJ (2006) DNA sequence comparisons of Ophiostoma spp., including Ophiostoma aurorae sp. nov., associated with pine bark beetles in South Africa. Stud Mycol 55:269-277

Zhou XD, Jacobs K, Kirisits T, Chhetri DB, Wingfield MJ (2008) Leptographium bhutanense sp. nov., associated with the root collar weevil Hylobitelus chenkupdorjii on Pinus wallichiana in Bhutan. Persoonia 21:1-8

Zipfel RD, de Beer ZW, Jacobs K, Wingfield BD, Wingfield MJ (2006) Multi-gene phylogenies define Ceratocystiopsis and Grosmannia distinct from Ophiostoma. Stud Mycol 55:75-97 